This item was submitted to Loughborough's Research Repository by the author.

Items in Figshare are protected by copyright, with all rights reserved, unless otherwise indicated.

\title{
A systematic review of current understandings of employability
}

PLEASE CITE THE PUBLISHED VERSION

http://dx.doi.org/10.1080/13639080.2015.1102210

PUBLISHER

(c) Taylor and Francis

\section{VERSION}

AM (Accepted Manuscript)

\section{PUBLISHER STATEMENT}

This work is made available according to the conditions of the Creative Commons Attribution-NonCommercialNoDerivatives 4.0 International (CC BY-NC-ND 4.0) licence. Full details of this licence are available at: https://creativecommons.org/licenses/by-nc-nd/4.0/

\section{LICENCE}

CC BY-NC-ND 4.0

\section{REPOSITORY RECORD}

Williams, Stella, Lorna J. Dodd, Catherine Steele, and Raymond Randall. 2019. "A Systematic Review of Current Understandings of Employability". figshare. https://hdl.handle.net/2134/19805. 


\section{A systematic review of current understandings of employability}

Stella Williams ${ }^{a}$, Lorna Dodd ${ }^{a}$, Catherine Steele ${ }^{b}, R^{2}$ aymond Randall ${ }^{c}$

${ }^{a}$ Psychology and Counselling, Newman University, Birmingham, England. ' ${ }^{b}$ sychology,

University of Leicester, Leicester, England. Loughborough University, Leicester, England. 
A theoretical framework is essential for the effective evaluation of employability (Clarke, 2008; Harvey, 2001). However, there are a wide range of definitions of employability coexisting in current literature (Harvey, 2001; Nauta, van Vianen, van der Heijden, van Dam, \& Willemsen, 2009). A review into existing ways in which employability has been conceptualised is needed to inform a better understanding of the nature of contributions made by various employability development opportunities, and appropriate assessment of these contributions. A systematic review is presented, assessing the similarities and differences between the components of employability conceptualisations, focusing on employability at an individual level (Thijssen, Van der Heijden, \& Rocco, 2008). Relevant publications were identified through a sensitive search strategy of eight electronic bibliographic databases from 1960 to 2014. Data was extracted from 16 eligible manuscripts. Capital, career management and contextual dimensions were identified as unifying themes in these components. Findings indicate that success in developing employability needs to be contextualised within a conceptualisation of employability as a multifaceted construct.

Keywords: employability; review; career management; capital; signalling. 


\section{Introduction}

Over the decades the way in which employability has been described has fluctuated, along with the changing contexts in which individuals have sought employment (Grazier, 1998). A review of the concept of employability from the 1940's to 1990's indicates a move from a dichotomy of either being employable or not, to a consideration of employability as having a dynamic adaptive nature (Grazier, 1998). Thus, theories of employability have become increasingly complex, and multi-dimensional.

Although there is agreement around the 'changing' nature of employability, defining employability in today's society is more difficult, with a wide range of definitions coexisting in present literature (Harvey, 2001; Nauta et al., 2009). A discussion paper by Harvey (2001) identified trends in conceptualising employability as both continuous and distinct from employment, being constantly developed through an accumulation of new knowledge and experience throughout an individual's lifetime. This personal development merely increases the probability of gaining employment but does not guarantee it. Employability is also often acknowledged to be variable depending on the context in which it is viewed; the country, timeframe and economic situation will influence the nature of employability.

Nevertheless, definitions have varied in their incorporation of these above components as well as their consideration of other components such as job satisfaction, employer satisfaction, job success, maintaining and retaining employment, and employee potential (de Grip, van Loo, \& Sanders, 2004; Fugate, Kinicki, \& Ashforth, 2004; Hillage \& Pollard, 1998; Van Der Heijde \& Van Der Heijden, 2006). Indeed it may be considered naive to think that a single dominant definition of employability exists. In reality one must first identify the perspective from which the term is being applied. A plurality of stakeholders take a perspective on employability, each holding a different approach and scope and serving to highlight different issues and domains of action in which they work.

Thijssen, Van der Heijden, and Rocco (2008) distinguished between three perspectives from which employability can be viewed, 1) societal, referring to employment rates and economic health, 2) company or organisational, focusing on the individuals within that company and whether supply meets demand; and 3) individual, which pertains to 'an indicator of his or her opportunity to acquire and to keep an attractive job in the internal or external labour market' (Thijssen et al., 2008, p.168).

Focus on the individual level of employability, as suggested from Grazier's (1998) documentation of changes throughout the decades, has gained considerable momentum. Discussion of the protean career and the rise in discussion of the boundariless career indicate that focus on the individual's perspective on employability is becoming ever greater. 
Given the investment required from individuals to develop and maintain their employability, both in terms of time and money, it is important to access accurate information around the contributions of development opportunities. Presently, dissatisfaction has been voiced around how employability is assessed, for example within Higher Education (HE) (Harvey, 2001). The current approach to this assessment has been referred to as subverting the operationalisation process, failing to first define the construct of employability and identifying its components before offering recommendations as to their relevant indicators (Harvey, 2001). This sentiment is supported by Clarke (2008) who argues that a theoretical framework is essential for the effective evaluation of employability. This situation suggests that there is merit to a clearer discussion of components playing out in employability.

The present review is performed in light of the significance of this individual level of employability to current debates in the literature, and the need for accurate information around the relative success of various employability development opportunities. The objective of this review is to provide the first systematic review of existing conceptualisations of employability. Differences and similarities between the components within employability conceptualisations will be identified. This will inform an understanding of methodologies for enhancing employability at the level of the individual, informing the employability development processes of both individuals and organisations.

\section{Method}

\section{Search strategy}

Relevant manuscripts were extracted using a sensitive search strategy. The following eight bibliographic databases were searched for relevant publications from January 1960 to May 2014; PsycArticles, PsycINFO, Business Source Elite, Educational Research Complete, Psychology and Behavioural Science Collection, Web of Science, SCOPUS and Expanded Academic. Additionally, ProQuest Databases and Index to Theses in Great Britain were explored for the purposes of identifying grey literature.

Additional citations were subsequently gathered through the reviewing of reference lists of appropriate manuscripts pertaining to employability.

The search strategy included the following keywords to identify appropriate sources: defin*, operationali*, model, framework, concept*, theor*, holistic and perspective. These were combined with the term 'employability'.

\section{Selection strategy}


To capture all pertinent titles, inclusion criteria were kept broad. Initially, titles and/or abstracts were included and full manuscripts were retrieved for further scrutiny if the manuscript referred to a conceptualisation (e.g. a model, framework or theory) of employability. Where the title or abstract provided insufficient information regarding its relevance to the inclusion criteria the full manuscript was retrieved and reviewed before a decision regarding inclusion was made.

Manuscripts that met the following inclusion criteria were accepted into the review; those that (1) were written in the English language; (2) aimed to provide a holistic conceptualisation of employability; (3) concerned the development of an individual's employability.

\section{Review strategy}

A data extraction form was applied systematically to each eligible manuscript that met the inclusion criteria. Components within the conceptualisation (e.g. those that make up the conceptualisation) were then extracted. Components were identified as such through review of model illustrations and the use of lists or categories presented by the authors of the reviewed manuscripts.

Components were subcategorised for the purposes of the present review through the use of a content analysis approach. Descriptions/definitions of components were used to identify overlaps in these components and thus allow grouping across different conceptualisations. For example, similarities in the definitions of Hillage and Pollard's (1998) 'assets' and Van Der Heijde and Van Der Heijden's (2006) 'occupational expertise' as ingredients that could be utilised to indicate economic gain for the individual resulted in these components being grouped together.

\section{Procedure}

Following the retrieval of full manuscripts of eligible publications that met the initial inclusion criteria, each manuscript was systematically scrutinised via the data extraction sheet process. Fifty percent of the extracted manuscripts were examined by co-authors as a reliability precaution.

\section{Results}

\section{Trial flow}

The initial systematic search strategy identified a total of 3744 potentially relevant citations. Of these, 463 were duplications; a further 3265 were disregarded for not 
meeting the initial inclusion criteria. Full manuscripts were then retrieved for the 16 remaining manuscripts and these were subject to a full data extraction. See table one for details of extracted manuscripts. 
Table 1. Details of extracted papers from which the latest information regarding employability conceptualisations is sourced

\begin{tabular}{|c|c|c|c|c|c|c|}
\hline Author & Year & Aim of paper & $\begin{array}{l}\text { Type of } \\
\text { paper }\end{array}$ & Sample & Method & Main outcomes \\
\hline $\begin{array}{l}\text { Hogan, } \\
\text { Chamorro- } \\
\text { Premuzic, and } \\
\text { Kaiser }\end{array}$ & 2013 & $\begin{array}{l}\text { To bridge the gap } \\
\text { between psychological } \\
\text { theory and employers } \\
\text { perceptions of } \\
\text { employability } \\
\text { determinates }\end{array}$ & $\begin{array}{l}\text { Position } \\
\text { paper }\end{array}$ & na & na & $\begin{array}{l}\text { Presentation of a proposed } \\
\text { model for understanding the } \\
\text { determinates of employability }\end{array}$ \\
\hline Bridgstock & 2009 & $\begin{array}{l}\text { To present a } \\
\text { conceptualisation of } \\
\text { desired graduate } \\
\text { attributes which } \\
\text { incorporates career } \\
\text { management skills }\end{array}$ & $\begin{array}{l}\text { Position } \\
\text { paper }\end{array}$ & na & na & $\begin{array}{l}\text { Production of a conceptual } \\
\text { framework made up of the } \\
\text { following components; } \\
\text { Self-management and career } \\
\text { building skills. } \\
\text { Acquisition, display and use } \\
\text { of discipline specific skills } \\
\text { and generic skills. As well as } \\
\text { underlying traits and } \\
\text { dispositions. }\end{array}$ \\
\hline $\begin{array}{l}\text { Thijssen, Van der } \\
\text { Heijden, and } \\
\text { Tonette }\end{array}$ & 2008 & $\begin{array}{l}\text { To offer a critical analysis } \\
\text { of employability } \\
\text { including its components }\end{array}$ & $\begin{array}{l}\text { Review of } \\
\text { literature }\end{array}$ & na & na & $\begin{array}{l}\text { Development of the } \\
\text { employability-link model }\end{array}$ \\
\hline Tomlinson & 2007 & $\begin{array}{l}\text { Explore how students } \\
\text { leaving higher education }\end{array}$ & $\begin{array}{l}\text { Empirical } \\
\text { paper }\end{array}$ & $\begin{array}{l}53 \text { final year pre } \\
1992 \text { undergraduate }\end{array}$ & $\begin{array}{l}\text { Semi-structured } \\
\text { interviews. }\end{array}$ & $\begin{array}{l}\text { Identification of two different } \\
\text { orientations and attitudes to }\end{array}$ \\
\hline
\end{tabular}




\begin{tabular}{|c|c|c|c|c|c|c|}
\hline & & $\begin{array}{l}\text { understand and manage } \\
\text { their employability }\end{array}$ & & students & $\begin{array}{l}\text { Analytical technique } \\
\text { unknown. }\end{array}$ & $\begin{array}{l}\text { work: } \\
\text { Passive/active career } \\
\text { development (means) } \\
\text { Market/ non market career } \\
\text { aspirations (end) }\end{array}$ \\
\hline $\begin{array}{l}\text { Dacre Pool and } \\
\text { Seweller }\end{array}$ & 2007 & $\begin{array}{l}\text { Introduce a practical } \\
\text { model of employability to } \\
\text { be used by students to } \\
\text { develop their } \\
\text { employability }\end{array}$ & $\begin{array}{l}\text { Position } \\
\text { paper }\end{array}$ & na & na & $\begin{array}{l}\text { Development of the 'key to } \\
\text { employability' model }\end{array}$ \\
\hline $\begin{array}{l}\text { Van Der Heijden } \\
\text { and Van Der } \\
\text { Heijden }\end{array}$ & 2006 & $\begin{array}{l}\text { To present an instrument } \\
\text { for measuring } \\
\text { employability }\end{array}$ & $\begin{array}{l}\text { Empirical } \\
\text { paper }\end{array}$ & $\begin{array}{l}314 \text { employees and } \\
334 \text { immediate } \\
\text { supervisors (290 } \\
\text { pairs) }\end{array}$ & $\begin{array}{l}\text { Ratings on items } \\
\text { designed by authors to } \\
\text { measure Occupational } \\
\text { Expertise, Anticipation } \\
\text { and Optimisation; } \\
\text { Personal Flexibility; } \\
\text { Corporate Sense; and } \\
\text { Balance }\end{array}$ & $\begin{array}{l}\text { Results supported the } \\
\text { reliability and validity of the } \\
\text { measurement tool and } \\
\text { identified that Occupational } \\
\text { Expertise, Anticipation and } \\
\text { Optimisation; Personal } \\
\text { Flexibility; Corporate Sense; } \\
\text { and Balance explained a } \\
\text { significant amount of } \\
\text { variation in objective and } \\
\text { subjective measures of career } \\
\text { success. }\end{array}$ \\
\hline McQuaid and & 2005 & $\begin{array}{l}\text { To analyse current and } \\
\text { previous applications of }\end{array}$ & Review of & na & na & Present conceptualisation of \\
\hline
\end{tabular}




\begin{tabular}{|c|c|c|c|c|c|c|}
\hline Lindsay & & $\begin{array}{l}\text { the term employability } \\
\text { and its value as an } \\
\text { exploratory concept and a } \\
\text { framework for policy } \\
\text { analysis. (p. 197) }\end{array}$ & literature & & & employability. \\
\hline $\begin{array}{l}\text { McArdle, Waters, } \\
\text { Briscoe and Hall }\end{array}$ & 2007 & $\begin{array}{l}\text { To empirically test } \\
\text { Fugate, Kinicki, and } \\
\text { Ashforth’s } 2004 \text { model } \\
\text { (p. 247). }\end{array}$ & $\begin{array}{l}\text { Empirical } \\
\text { paper }\end{array}$ & $\begin{array}{l}416 \text { unemployed } \\
\text { Australians }\end{array}$ & $\begin{array}{l}\text { Longitudinal survey } \\
\text { study. Follow up at six } \\
\text { months. Surveys } \\
\text { included; Bateman and } \\
\text { Crant’s (1993) } \\
\text { proactivity personality } \\
\text { scale; Stumpf, Colarelli } \\
\text { and Hartman's (1983) } \\
\text { Identity Awareness } \\
\text { scale; Messer } \\
\text { and Harter’s (1985) } \\
\text { self-esteem scale; and } \\
\text { Kinicki and Latack’s } \\
\text { (1990) Job search } \\
\text { behaviour scale }\end{array}$ & $\begin{array}{l}\text { The paper offered support for } \\
\text { identity awareness, proactive } \\
\text { personality, self-esteem and } \\
\text { job search components on job } \\
\text { searching and reemployment } \\
\text { outcomes within } \\
\text { an unemployed population }\end{array}$ \\
\hline $\begin{array}{l}\text { deGrip, Van loo } \\
\text { and Sanders }\end{array}$ & 2004 & $\begin{array}{l}\text { Presentation of an } \\
\text { Industry Employability } \\
\text { Index for cross-sectorial } \\
\text { analysis of employability }\end{array}$ & $\begin{array}{l}\text { Empirical } \\
\text { research }\end{array}$ & $\begin{array}{l}13 \text { sectors of the } \\
\text { Dutch economy }\end{array}$ & $\begin{array}{l}\text { Statistical analysis of } \\
\text { secondary data sourced } \\
\text { from multiple locations } \\
\text { including; the labour } \\
\text { supply and labour } \\
\text { demand survey, labour }\end{array}$ & $\begin{array}{l}\text { Sector comparisons of } \\
\text { employability index. }\end{array}$ \\
\hline
\end{tabular}




\begin{tabular}{|c|c|c|c|c|c|c|}
\hline & & & & & $\begin{array}{l}\text { force survey } \\
\text { the labour supply and } \\
\text { labour demand surveys } \\
\text { of the Organisation for } \\
\text { Strategic Labour } \\
\text { Market Research } \\
\text { (OSA) } \\
\text { and the labour force } \\
\text { survey of Statistics } \\
\text { Netherlands (CBS). }\end{array}$ & \\
\hline Forrier and Sels & 2003 & $\begin{array}{l}\text { To develop a conceptual } \\
\text { model } \\
\text { of the 'employability } \\
\text { process' (p. 102) }\end{array}$ & $\begin{array}{l}\text { Position } \\
\text { paper }\end{array}$ & na & na & $\begin{array}{l}\text { A conceptual model is } \\
\text { presented }\end{array}$ \\
\hline $\begin{array}{l}\text { Brown, Hesketh, } \\
\text { and Williams }\end{array}$ & 2003 & $\begin{array}{l}\text { To examine the concept } \\
\text { of employability and to } \\
\text { identify flaws in the way } \\
\text { employability is typically } \\
\text { defined within official } \\
\text { statements }\end{array}$ & $\begin{array}{l}\text { Position } \\
\text { paper }\end{array}$ & na & na & $\begin{array}{l}\text { The application of positional } \\
\text { conflict theory to } \\
\text { employability }\end{array}$ \\
\hline Knight and Yorke & 2003 & $\begin{array}{l}\text { Review current responses } \\
\text { to expectations around } \\
\text { HE as an employability } \\
\text { development system. }\end{array}$ & $\begin{array}{l}\text { Position } \\
\text { paper }\end{array}$ & na & na & $\begin{array}{l}\text { Presentation of the USEM } \\
\text { employability model }\end{array}$ \\
\hline
\end{tabular}




\begin{tabular}{|c|c|c|c|c|c|c|}
\hline & & $\begin{array}{l}\text { Including an analysis of } \\
\text { the concept of } \\
\text { employability }\end{array}$ & & & & \\
\hline $\begin{array}{l}\text { Harvey, Locke, } \\
\text { and Morey }\end{array}$ & 2002 & $\begin{array}{l}\text { To report on the links } \\
\text { between higher education } \\
\text { and the world of work }\end{array}$ & Report & $\begin{array}{l}\text { Sixteen higher } \\
\text { education } \\
\text { institutions }\end{array}$ & Case studies & $\begin{array}{l}\text { Recommendations to CSU } \\
\text { and other HE agencies, } \\
\text { institutions, employers and } \\
\text { their representative bodies for } \\
\text { the enhancement of links } \\
\text { between HE and the world of } \\
\text { work }\end{array}$ \\
\hline $\begin{array}{l}\text { Kluytmans and } \\
\text { Ott }\end{array}$ & 1999 & $\begin{array}{l}\text { To explore how } \\
\text { employers can offer } \\
\text { security for employee's } \\
\text { (p. 261) }\end{array}$ & $\begin{array}{l}\text { Position } \\
\text { paper }\end{array}$ & na & na & $\begin{array}{l}\text { Identifies those employees } \\
\text { with little training as most } \\
\text { vulnerable within the labour } \\
\text { market. Suggest combining } \\
\text { functioning and broadening } \\
\text { tasks to increase job security }\end{array}$ \\
\hline $\begin{array}{l}\text { Hillage and } \\
\text { Pollard }\end{array}$ & 1998 & $\begin{array}{l}\text { To help inform future } \\
\text { policy development (p. } \\
\text { ix) }\end{array}$ & Report & $\begin{array}{l}\text { DfEE officials and } \\
\text { external experts and } \\
\text { commentators. } \mathrm{N}= \\
\text { unknown }\end{array}$ & Interviews & $\begin{array}{l}\text { Development of conceptual } \\
\text { framework. } \\
\text { Response from interviews } \\
\text { unknown }\end{array}$ \\
\hline $\begin{array}{l}\text { Eby, Butts and } \\
\text { Lockwood }\end{array}$ & 2003 & $\begin{array}{l}\text { To examine three career } \\
\text { competencies important } \\
\text { for a boundariless career. } \\
\text { These mirror Arthurs }\end{array}$ & $\begin{array}{l}\text { Empirical } \\
\text { paper }\end{array}$ & $\begin{array}{l}458 \text { alumni of a } \\
\text { single university }\end{array}$ & $\begin{array}{l}\text { Questionnaires. } \\
\text { 'knowing why' } \\
\text { predictors (proactive } \\
\text { personality, openness }\end{array}$ & $\begin{array}{l}\text { Twenty-six percent of } \\
\text { variance in measures of } \\
\text { perceived career success } \\
\text { (career satisfaction, internal } \\
\text { marketability and external }\end{array}$ \\
\hline
\end{tabular}




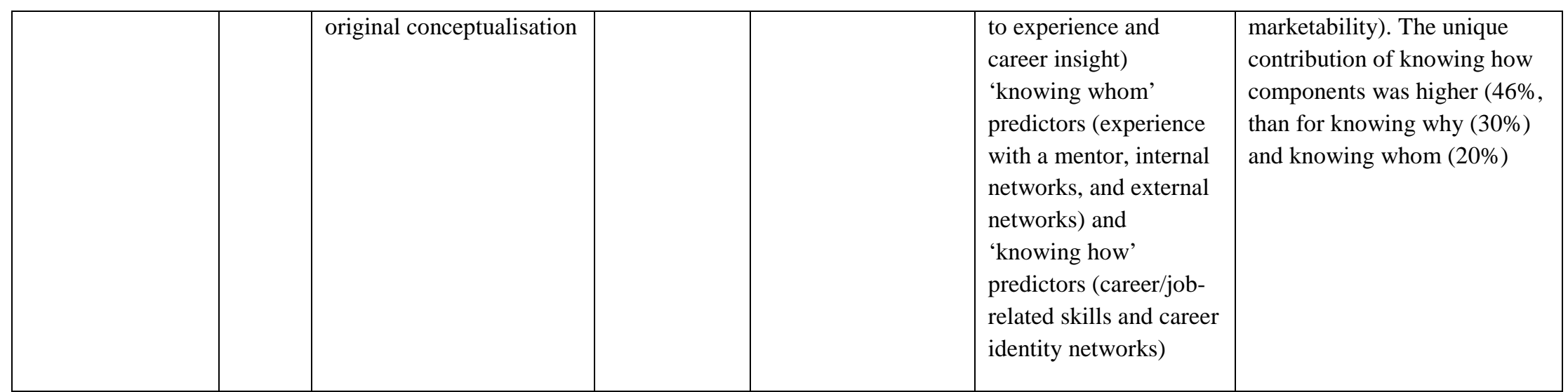

N.b. where subsequent testing of the model has occurred this paper replaces original conceptualisation 


\section{Characteristics of employability conceptualisations}

Eighty-eight components were identified from the 16 conceptualisations. Components were seen as any aspect explicitly labelled as a core part of the overall conceptualisation. Unifying themes in these components were identified, providing one superordinate dimension, capital, which can be separated into four subordinate dimensions (human, social, cultural, and psychological). The value of this capital in contributing towards the achievement of beneficial employability outcomes is then mediated by career management and contextual components. Table two presents a breakdown of papers according to their contributions to each dimension. Each of these will be defined in turn and a description of their development and empirical support will be presented.

\section{Dimension 1: Capital components}

\section{Definition and core features}

The unifying dimension of capital is broadly defined here as anything an individual possesses that can be seen as leading to an increased probability of positive economic outcomes, or other personal outcomes relating to the area of work. The core features of this dimension are properties of the individual that elicit demand or functionality in the workplace.

This superordinate dimension was further subdivided into four subordinate categories; human, social, cultural, and psychological. Fifteen of the 16 conceptualisations incorporate components of this kind (see table 2). The aspects of capital given centre stage vary.

\section{Dimension 1.1: Human capital}

Definition and core features

Human capital was referred to by Becker (1962) as information and skills that the individual possesses that are perceived as contributing to the production process. This capital cannot be separated from individuals and elicits favourable outcomes. Training and schooling are seen as investments in this capital.

As such, this dimension explains employability in terms of providing added functionality to the employer through an enhancement of the skills and knowledge available to them e.g. knowledge of the latest techniques or software that could lead to 
economic gain for the company. Employability from this dimension therefore relates to the degree to which the human capital someone possesses allows them to compete for their 'desired' job role. This desire will be informed by other dimension of employability.

\section{Dimension development}

Within the extracted manuscripts the first author to offer an employability conceptualisation that refers to components which can be understood in terms of human capital is Arthur, Claman, and DeFillippi (1995). Linked to employability by Eby, Butts and Lockwood (2003), Arthur et al's 'knowing how' component referred to the knowledge and skills that individuals bring to the firm through formal and experiential learning.

This dimension is then developed further within a later employability conceptualisation developed by Hillage and Pollard (1998). In this report capital is represented in the component 'assets'. There is then further subdivision into three categories; Baseline Assets, referring to basic skills and essential personal attributes; Intermediate Assets, referring to occupational specific skills, general key skills and key personal attributes; and High Skills, referring to skills that help contribute to organisational performance.

Since these conceptualisations, human capital components have been incorporated to varying degrees by others. For example, Knight and Yorke (2003) include a 'skills' component alongside reference to 'understanding'; Dacre-Pool and Sewell (2007) include 'degree subject knowledge, understanding and skills' and 'Generic skills'; Van Der Heijde and Van Der Heijden (2006) include 'occupational expertise' which the authors stated was growing in importance as a result of 'the intensification of knowledge' (p.454): and within Hogan, Chamorro-Premuzic, and Kaiser (2013) human capital is present as 'abilities, expertise and know-how which employers perceive as the candidates ability to 'do the job' (p.12).

All of these components refer to the properties an individual needs to possess to ensure functionality in the workplace and can be traded within the job market for economic gain. Employability is understood in terms of the match between this capital and the required capital of the desired post.

The gaining of capital is also discussed within these conceptualisations. Harvey, Locke, and Morey (2002) highlight the opportunities HE and extra-curricular experience offer for developing employability. This is brought forward and broadened by Dacre-Pool and Sewell (2007) who refer to the impact of both work and life experience on student employability development.

Despite regular inclusion within employability conceptualisations, it has proven difficult to pinpoint the necessary capital required for varying roles, due in part to the 
fluctuating nature of job requirements within today's society. Nevertheless, the role of capital in developing variables such as job performance and career consequences has been supported by a range of publications (QUIŃONES, Ford, \& Teachout, 1995; Shaffer, Kraimer, Chen, \& Bolino, 2012).

Within the extracted literature evidence for human capital's role in enhancing perceived career satisfaction, internal and external marketability was provided within Eby et al., (2003). This is confirmed by data extracted through consultation with key stakeholders (Hillage \& Pollard, 1998), reports from 314 employees and 334 immediate supervisors (290 pairs) (Van Der Heijde \& Van Der Heijden, 2006), reports from 458 alumni (Eby et al., 2003), as well as reports from 416 unemployed Australians (McArdle, Waters, Briscoe, \& Hall, 2007). It is undoubtedly a critical aspect of employability.

Notwithstanding the value of this capital, economic theory and wider empirical research suggest that human capital in and of itself may be considered too narrow a concept when looking at the properties of individuals which can lead to economic gain. More expansive discussions of capital have therefore dominated existing employability conceptualisations.

\section{Dimension 1.2: Social capital}

\section{Definition and core features}

Social capital was identified by Bourdieu (2008) as social obligations or connections seen as convertible to economic capital.

Social capital further explains the concept of employability through the additional value of existing relationships which can be utilised to enhance the economic capital of the company as a result of recruiting an individual e.g. Illustrating connections with investors that have previously been reluctant to engage with the company, who may reconsider given awareness of the new employee's involvement. Thus, from this dimension employability is the degree to which the potential employee possesses social connections that can be utilised to enhance their functionality in the workplace.

\section{Dimension development}

In Arthur et al., (1995) knowledge career framework - 'knowing whom' - was named as an important component for career success. Arthur et al., (1995) described this as career-related networks and contacts. Not long after this Fugate et al., (2004) also adopted 'social capital' as a component of their employability conceptualisation alongside 'human capital'. 
Both of these conceptualisations have been empirically tested and support for the unique contribution of this social element is provided (Eby et al., 2003; Fugate et al., 2004). External to these extracted papers, independent support for the role of social capital in employability understandings is offered in a number of works (e.g. Kwon \& Arenius, 2010; McArdle et al., 2007; Rynne, 2014).

\section{Dimension 1.3: Cultural capital}

Definition and core features

Dissatisfaction within the economic literature as to the narrow nature of human capital also introduced consideration of cultural capital. Cultural capital refers to situations which the individual has experienced that are perceived as enhancing the properties of the individual, which lead to functionality in the workplace (Bourdieu, 2008). This capital can also be converted into economic capital when needed.

This group of components offers an explanation of employability in terms of the impact of fit between the employer's ideas, customs and social behaviours and those of potential employees.. Enhanced similarity, or fit, provides increasing motivation to engage in the company's expected work practices, to strive for company goals and to thus enhance an individual's employability.

\section{Dimensions development}

A less dominant presence appears to be given to the importance of culture on the employability of individuals within the extracted manuscripts. Nevertheless, this dimension offers explanatory value to the overall conceptualisation of employability.

Cultural capital provides a link to a fuller understanding of the role of components such as the value of a degree and other experience (Harvey et al., 2002; Dacre-Pool \& Sewell, 2007) as well as current labour market positions (Forrier \& Sels, 2003) on employability. These components represent investments of time and/or money which introduce new levels of cultural capital. By engaging in these activities, individuals access prestige or enhance their status within a given setting.

Representations of fit between employer and employee have become increasingly prevalent in recent conceptualisations of employability. Van Der Heijde and Van Der Heijden (2006) introduced a 'balance' component, which represents the need to find a compromise between the values and expectations of the organisation and the values and expectations of the individual. More recently, Hogan, ChamorroPremuzic and Kaiser (2013) introduce the concept of employability as a form of socially desirable behaviour in which individuals are perceived by employers as 'fitting in' with the organisation to greater or lesser degrees. Again, this model emphasises the importance of social compatibility as one determinate of employability. 
In addition to these links to cultural capital presented within the extracted papers, external research indicates the presence of discrimination in selection processes (Forrier \& Sels, 2003; McQuaid \& Lindsay, 2005). This discrimination evidences a judgment of 'in' and 'out' groups within recruitment processes and an impact of these on process outcomes. Whilst certain acts of discrimination are tackled by legislation - e.g. discrimination on the basis of age, race, religion etc. - not all forms of 'in' and 'out' group comparisons are excluded in this way. This suggests potential value for social group membership and demographic components in developing our understanding of employability.

\section{Dimension 1.4: Psychological capital}

Definition and core features

Within the extracted manuscripts an additional distinct category of capital can be identified. Psychological capital relates to psychological capacities offering strengths within the job market. Described by its campaigner Luthans (2002), psychological capital relates to 'positively oriented human resource strengths and psychological capacities that can be measured, developed, and effectively managed for performance improvement in today's workplace' (Luthan 2002, p.59). This includes states such as confidence, hope, resilience, positive self-evaluation and personality traits such as conscientiousness.

Psychological capital adds to previous forms of capital, explaining employability from the standpoint of the individual's ability to offer optimal performance within the role offered e.g. providing confidence levels that will add credibility to their performance.

\section{Dimension development}

Perhaps unsurprisingly, given the description of the most recent wave of employability definitions (Grazier, 1998), adaptability and resilience are dominating aspects of psychological capital within the extracted manuscripts. Adaptability is defined here as the ability to change, or to be changed, to fit new circumstances. This was first considered within conceptualisations as 'willingness to be mobile' (Kluytmans \& Ott, 1999), followed by 'willingness to develop' (Harvey et al., 2002) and subsequently by 'willingness to move' and perceived 'ease of movement' (Forrier \& Sels, 2003), which Forrier and Sel termed 'movement capital'. Further references are made to this adaptability within McQuaid and Lindsay (2005) in the individual factors 'adaptability and mobility' and 'personal flexibility' and Eby et al.'s (2003) operationalisation of 'knowing why' to include 'readiness to adapt to circumstances'.

Adaptability as proactivity was discussed by Fugate et al., (2004) who acknowledged five individual differences relevant to personal adaptability; optimism, 
propensity to learn, openness, internal locus of control, and generalised self-efficacy. Later, Van Der Heijde and Van Der Heijden (2006) developed Fugate et al.'s work into their anticipation and optimisation component, which related to being proactive or selfinitiated. Van der Heijde and Van Der Heijden also discussed 'personal flexibility'. This component represented an individual's ability to adapt to change forced on them, presenting a smooth transition. Issues of resilience and coping were mentioned within this conceptualisation.

This aspect of psychological capital was further developed by de Grip et al., (2004) who conceptualised employability as three aspects of personal motivation to adapt; willingness to 'engage in training', willingness to 'be mobile' in reference to movement across job roles, and willingness to engage in 'functional flexibility' which brings this mobility into a consideration of current job role flexibility - seen as a method of developing capital. This emphasis on being functionally flexible to promote capacity to move beyond that role was later echoed by Thijssen et al., (2008) in which an individual's learning skills and mobility skills influence an individual's ability to broaden their capital and transition to other positions.

In addition to references around adaptability, self-efficacy (Knight \& Yorke, 2003; Dacre-Pool \& Sewell, 2007) openness (Bridgstock, 2009), and ambition (Hogan, Chamorro-Premuzic, and Kaiser, 2013) have also been discussed in relation to conceptualisations of employability. In more recent work Bridgstock (2009) notes the role of 'underpinning traits and dispositions' and Hogan, Chamorro-Premuzic and Kaiser (2013) discuss candidate's profiles, which includes a consideration of ambition, work ethic, and drive.

There is an array of supporters for this strong presence within the extracted papers of the role of psychological capital. McArdle et al., (2007) present a longitudinal study within the unemployed population, supporting a positive relationship between proxy measures of adaptability with measures of employability. Similarly, literature exploring the boundariless career mind-set emphasises a fluid approach to employability that goes beyond set job roles (Briscoe \& Hall, 2006; De Vos \& Soens, 2008). There is also a wealth of research into the protean personality /attitude towards work, which identifies adaptability as a career meta-competence that facilitates a protean career (Hall, 2004).

There is also an abundance of support for the role of self-efficacy in understanding employability. A meta-analysis by Judge and Bono (2001), showed a positive relationship between generalised self-efficacy and job satisfaction and performance. Further empirical research into the impact of self-efficacy on employability related variables suggests that, as with other work addressing selfefficacy (Bandura, 1997), a specific focus on career self-efficacy is of value to this discussion (e.g. McArdle et al., 2007; Nauta et al., 2009). 
Despite the core focus on capital within the majority of these conceptualisations, evidence from the review also points towards an equally important role for communication of this capital within the process of job searching and application.

\section{Dimension 2: Career management}

\section{Definition and core features}

Evident within the extracted manuscripts is an ever-increasing importance placed on career management as a component of employability. This indicates the need to consider employability in terms of competencies and skills beyond performance in a set job role, as well as the role of career goals/ orientation in outlining an individual's desired employment.

This dimension's core features relate to the explanation of employability in terms of an individual's competence in navigating the labour market in order to achieve their personal career goals through access to relevant training and employment opportunities. A distinction is made here between two aspects of career management; signal-management and self-management. This dimension of employability conceptualisation was eluded to within 13 of the 16 conceptualisations (see table 2).

\section{Dimension 2.1: Signal management}

Definition and core features

An alternative to previously mentioned perspectives on capital comes from the work of Spence (1973) on signalling theory. This theory postulates that inferences are drawn around the 'capital' of individuals through signals rather than directly. It is these interpretations of signals that influence the attainment of economic and other gains.

Signalling is made up of three key aspects, the first being the signaller, e.g. the job candidate, who holds private information that would be of benefit to the other party. The second is the signal, intentionally indicating positive or negative information of value to the other party. Lastly there is the receiver, e.g. the recruiter, the 'other party' involved in the decision making process who benefits from the communication of accurate signals (Connelly, Certo, Ireland, \& Reutzel, 2011).

Within this dimension signalling processes are further expanded to include the role of skills and knowledge necessary for the identification of relevant signalling opportunities and understanding of how to present these signals effectively. As such employability viewed from this dimension relates to an individual's ability to navigate and engage with selection and recruitment opportunities, which will lead them closer to their desired career goals. 


\section{Dimension development}

The process of signalling was referred to in connection with holistic conceptualisations of employability by Forrier and Sels (2003), who suggested its value in understanding the abilities offered by potential employees. The role of both presenting signals and understanding the processes and opportunities that require these signals are presented within the majority of extracted employability conceptualisations.

Hillage and Pollard (1998) refer to the role of recruitment and selection behaviour and the job matching process as well as job searching and strategic approaches to securing employment. This supports the need for knowledge and skills around the selection of signalling opportunities. They also include the component of articulating your assets (Capital), which links to the importance of effectively presenting signals. This aspect of employability was carried forward by Harvey et al., (2002) as 'articulation of employability', another component Harvey saw as having a 'core impact' on employability. Subsequently, 'job seeking' (McQuaid and Lindsay, 2005), career development learning (Dacre-Pool \& Sewell, 2007), cooperate sense (Van Der Heijde and Van Der Heijden (2006) and career building skills (Bridgstock, 2009) have been linked to employability.

Connections have also been made to the role of networking and social capital in navigating signalling opportunities. Hillage and Pollard (1998) discuss having access to important networks as an aspect of their deployment component. Not long after this Kluytmans and Ott (1999) introduced 'job market know-how', which included engaging in regular exchange of information through formal and informal networks.

Additionally, this dimension encompasses an understanding of how objectified and institutionalised forms of cultural capital factor into our understanding of employability. These offer signals in the form of qualifications and possessions, demonstrating common ways of thinking (cultural capital) that are seen as representing increased employability.

These contributions emphasise the wider role of managing signals through knowledge and awareness of signalling processes and opportunities to so present effective signals. Whilst empirical support for the contribution of signalling and signalling processes is absent within the extracted manuscripts, support has been offered by papers supplementary to those reviewed (e.g. Arkes, 1999; Connelly et al., 2011; Smetherham, 2006; Werbel, 2000).

It must also be highlighted that - perhaps in an attempt to justify employee selection within otherwise matched samples of applicants - employer requirements for qualifications, such as degrees, have increasingly been applied to roles that arguably do not require the levels of knowledge advertised for and assessed against. This in turn has resulted in a field categorised by employability literature as under-employment, in which the full potential of individuals is not developed by a role, not necessarily as a 
result of that individual's values or goals as represented within the self-management dimension, but rather as a result of inappropriate signals required by employers within their selection processes. An example would be the requirement for degree-level study of information technology for predominantly script-based technical support roles.

\section{Dimension 2.2: Self- management skills}

Definition and core features

Complimenting signal-management in our understanding of employability, selfmanagement skills are modelled here on the definition provided by Bridgstock (2009). This dimension represents the impact of 'the individual's perception and appraisal of themselves in terms of values, abilities, interests and goals.' (Bridgstock, 2009, p37).

These values, interests and so forth provide a context in which that individual sees employment. These issues will inform the way in which they approach the world of work and the outcomes they aim to achieve from itand from signalling processes. Encompassed within this dimension is an awareness of the importance of career identity. Whilst career identity informs acceptable career goals and means of achieving these goals, based on an individual's interests, values and motives, the present selfmanagement dimension expands upon this to include the importance of accurately appraising one's abilities and values.

The core features of this dimension are elements of an individual's feelings or values influencing how they relate to the working world. This in turn influences which opportunities presented in the context are pursued, and what actions to develop or apply capital (and thus develop or present 'signals') the individual is motivated to engage in. As such employability derived from this dimension relates to the achievement of 'personal goals' and 'employee career satisfaction' through the matching of these goals with available opportunities.

\section{Dimension development}

Hillage and Pollard (1998) integrate this component into their conceptualisation in the form of 'deployment'. Deployment refers to the awareness an individual has of their capital and how this awareness is actively used. Since Hillage and Pollard (1998) the process of reflection and evaluating has been considered in terms of employability (Harvey et al., 2002; Dacre-Pool \& Sewell, 2007), as has metacognition (Knight \& Yorke, 2003). Furthermore, Harvey et al. (2002) highlighted 'self-reflection' as another of the core impacts on employability. Without this self-awareness individuals are unable to present necessary signals to their capital irrespective of their possession of the capital and participation in the relevant signalling processes. 
In addition to the role of self-reflection/awareness regarding the capital an individual possesses, there is also an important part to be played by the personal identity of the individual. It is this identity that leads to drive, individual goals and opportunity preferences. Identity is referred to in relation to a conceptualisation of employability within Fugate et al. (2004) as a psychosocial construct encompassing 'goals, hopes, and fears; personality traits; values, beliefs, and norms; interaction styles; time horizons; and so on' (p. 20).

Moreover, Tomlinson (2007), who identifies his conceptualisation as being one of employability, presented an identity model with two distinct aspects of how an individual positions themselves in terms of their approach to work and development, and to their career goals. This link between identity and how an individual approaches work evidences the relationship between identity and 'drive' or 'ambition'; motivational components included within Hogan, Chamorro-Premuzic, and Kaiser’s (2013) conceptualisation of employability in which they see employers interpreting this as a 'willingness to work'. This could also be linked to 'willingness' components mentioned within the psychological capital grouping presented earlier.

Support for the role of identity within these extracted manuscripts is again prolific. Investigations into the perceived career success and perceived internal and external marketability of alumni students by Eby et al.,'s (2003) found that 'knowing why' components, incorporating aspects of identity, contribute to an overall explanation of $44 \%$ of the variance in these employment outcomes. Furthermore, results from research into the impact of identity on career suitability and outcomes provides support for variations in career identity and for the impact of these on employment outcomes (Brown \& Hesketh, 2004).

Whilst representation of orientation models such as Tomlinson's is limited in this review due to the stated inclusion criteria, this literature shows support for the role of career identity in understanding employability (e.g.Nauta et al., 2009; Van Dam, 2004).

Given this dimension's prevalence within extracted manuscripts, further consideration of career management and orientation models may be beneficial to the development of a more complete understanding of employability.

\section{Dimension 3: Contextual components}

\section{Definition and core features}

This final dimension refers to the surrounding events and systems that make up each individual employment opportunity. As with career management components, these negotiate the impact of capital components on employability. The core features of this dimension are external circumstances that influence the capital demanded of an 
individual. Therefore, employability as seen from this dimension relates to the fit between the individual and the employer's current requirements compared to the fit of other individuals applying for this role. This dimension illustrates how the weights of various aspects of capital vary within each recruitment scenario.

Context was discussed in relation to all conceptualisations, but was explicitly incorporated as components within 11 conceptualisations out of the 16 (see table 2).Dimensions development

Perhaps the most significant theoretical development in relation to contextual factors is the work of Brown, Hesketh and Williams (2003). This conceptual framework presents employability in terms of Positional Conflict Theory. This theory goes beyond a consideration of a meritocratic context, in which those most qualified receive job opportunities, to an expansion of Conflict Theory that discusses employability in terms of a justification for unequal opportunities. Employability is seen as not just the outcome of absolute employability, being the capital held by an individual, but also relative employability, being the comparison between our capital and the capital of those we are compared to. As such, the work of Brown and colleagues explores the roles of globalisation and mass education on labour market demand.

Another significant contribution to our understanding of the employability context is the work of de Grip et al., (2004). Alongside a consideration of the individual's mobility, training and functional flexibility, this work presents a taxonomy of development that leads to changes in the demand for employability as presented by employers. This work provides support, at the sector level, for the effect of demographic, economic, organisational and technological developments in obsolescing previous human capital and adding value to alternative human capital. For further details and illustrations of these contextual factors, the reader is advised to consider review of de Grip et al., (2004).

In addition to these major contributors to the development of contextual components of employability, Personal circumstances such as 'caring responsibilities, disabilities, and household status' (Hillage \& Pollard, 1998, p.86) access of opportunities (McQuaid and Lindsay (2005) and Thijssen et al., (2008) and broadening and transition conditions are also represented within the extracted papers as impacting upon the ability of individuals to navigate the labour market.

Support for the role of context in employability is strong. A review of the human resource development and economic literature by de Grip et al., (2004) concludes this 'clearly show[s] that it [an understanding of employability] has to encompass both individual and contextual factors’ (de Grip et al., 2004, p.212).

The nature of this dimension supports the statement by Cremin (2009) that there can be no formal or static definition of employability as individuals active within a competitive job market context strive constantly to keep ahead of others, and thus 
employability is a 'condition that can never be fulfilled' (p.131). Employability levels fluctuate with capital demand, resulting in higher requirements for employment in instances of under demand, wherein employers may be regarded as occupying a stronger bargaining position, and lower thresholds for employment in circumstances of over demand. 
Table 2. Dimensions present within extracted conceptualisations.

\begin{tabular}{|c|c|c|c|c|c|c|c|}
\hline \multirow{3}{*}{$\begin{array}{l}\text { Conceptualis } \\
\text { ations }\end{array}$} & \multicolumn{7}{|c|}{ Dimensions present within conceptualisation } \\
\hline & \multicolumn{3}{|c|}{ Capital } & \multicolumn{2}{|c|}{ Career Development } & \multicolumn{2}{|c|}{ Contextual } \\
\hline & Human & Social & $\begin{array}{l}\text { Psycholo } \\
\text { gical }\end{array}$ & $\begin{array}{c}\text { Signal- } \\
\text { manage } \\
\text { ment }\end{array}$ & $\begin{array}{c}\text { Self- } \\
\text { manage } \\
\text { ment }\end{array}$ & $\begin{array}{l}\text { Capital } \\
\text { Demand }\end{array}$ & Culture \\
\hline $\begin{array}{l}\text { Hogan, } \\
\text { Chamorro- } \\
\text { Premuzic, and } \\
\text { Kaiser }\end{array}$ & $\begin{array}{l}\text { Abilities, } \\
\text { expertise, } \\
\text { know-how }\end{array}$ & & & & $\begin{array}{l}\text { Ambition } \\
\text {, work } \\
\text { ethic, } \\
\text { drive }\end{array}$ & & $\begin{array}{l}\text { Social/interpe } \\
\text { rsonal } \\
\text { compatibility }\end{array}$ \\
\hline Bridgstock & $\begin{array}{l}\text { Discipline } \\
\text { specific } \\
\text { skills } \\
\text { Generic } \\
\text { skills }\end{array}$ & & $\begin{array}{l}\text { Underpin } \\
\text { ning traits } \\
\text { and } \\
\text { dispositio } \\
\text { ns }\end{array}$ & $\begin{array}{l}\text { Career } \\
\text { building } \\
\text { skills }\end{array}$ & $\begin{array}{l}\text { Self- } \\
\text { managem } \\
\text { ent skills }\end{array}$ & & \\
\hline $\begin{array}{l}\text { Thijssen, Van } \\
\text { der Heijden, } \\
\text { and Tonette }\end{array}$ & \multicolumn{3}{|c|}{$\begin{array}{l}\text { Current employability of human } \\
\text { resources }\end{array}$} & & & $\begin{array}{l}\text { Transition } \\
\text { conditions } \\
\text { and } \\
\text { Broadenin } \\
\text { g } \\
\text { conditions } \\
\text { (contextua } \\
\text { l) }\end{array}$ & $\begin{array}{l}\text { Transition } \\
\text { conditions } \\
\text { and } \\
\text { Broadening } \\
\text { conditions } \\
\text { (personal) }\end{array}$ \\
\hline Tomlinson & & & & & $\begin{array}{l}\text { Passive/a } \\
\text { ctive } \\
\text { career } \\
\text { developm } \\
\text { ent } \\
\text { (means) } \\
\text { Market/ } \\
\text { non } \\
\text { market } \\
\text { career } \\
\text { aspiration } \\
\text { s (end) }\end{array}$ & & \\
\hline $\begin{array}{l}\text { Dacre Pool } \\
\text { and Seweller }\end{array}$ & $\begin{array}{l}\text { Degree } \\
\text { subject } \\
\text { knowledg } \\
\text { e, } \\
\text { understan }\end{array}$ & & $\begin{array}{l}\text { Emotiona } \\
1 \\
\text { intelligen } \\
\text { ce }\end{array}$ & \multicolumn{2}{|c|}{$\begin{array}{l}\text { Career development } \\
\text { learning }\end{array}$} & & $\begin{array}{l}\text { Experience } \\
\text { (Work and } \\
\text { Life) }\end{array}$ \\
\hline
\end{tabular}




\begin{tabular}{|c|c|c|c|c|c|c|c|}
\hline & $\begin{array}{l}\text { ding and } \\
\text { skills } \\
\text { Generic } \\
\text { skills }\end{array}$ & & $\begin{array}{l}\begin{array}{l}\text { Self- } \\
\text { esteem }\end{array} \\
\text { Self- } \\
\text { efficacy } \\
\text { Self- } \\
\text { confidenc } \\
\text { e }\end{array}$ & & & & \\
\hline \multirow[t]{2}{*}{$\begin{array}{l}\text { Van Der } \\
\text { Heijden and } \\
\text { Van Der } \\
\text { Heijden }\end{array}$} & $\begin{array}{l}\text { Occupatio } \\
\text { nal } \\
\text { Expertise }\end{array}$ & & $\begin{array}{l}\text { Anticipati } \\
\text { on and } \\
\text { Optimisat } \\
\text { ion } \\
\text { Personal } \\
\text { Flexibilit } \\
\text { y }\end{array}$ & & & & Balance \\
\hline & & & & \multicolumn{2}{|c|}{ Corporate Sense } & & \\
\hline $\begin{array}{l}\text { McQuaid and } \\
\text { Lindsay }\end{array}$ & $\begin{array}{l}\text { Individual } \\
\text { factors } \\
\text { (Employab } \\
\text { ility skills } \\
\text { and } \\
\text { attributes) }\end{array}$ & & $\begin{array}{l}\text { Individua } \\
\text { l factors } \\
\text { (adaptabil } \\
\text { ity and } \\
\text { mobility) }\end{array}$ & $\begin{array}{l}\text { job } \\
\text { seeking }\end{array}$ & & $\begin{array}{l}\text { External } \\
\text { factors } \\
\text { (Demand } \\
\text { factors; } \\
\text { enabling } \\
\text { support } \\
\text { factors) }\end{array}$ & $\begin{array}{l}\text { Demographic } \\
\text { characteristic } \\
\text { s; health and } \\
\text { wellbeing; } \\
\text { Personal } \\
\text { circumstances } \\
\text { (Household } \\
\text { circumstances } \\
\text {; work } \\
\text { culture; } \\
\text { access to } \\
\text { resources) }\end{array}$ \\
\hline $\begin{array}{l}\text { Fugate, } \\
\text { Kinicki, and } \\
\text { Ashforth }\end{array}$ & $\begin{array}{l}\text { Human } \\
\text { Capital }\end{array}$ & $\begin{array}{l}\text { Social } \\
\text { Capita } \\
1\end{array}$ & $\begin{array}{l}\text { Personal } \\
\text { adaptabili } \\
\text { ty }\end{array}$ & & $\begin{array}{l}\text { Career } \\
\text { Identity }\end{array}$ & & \\
\hline $\begin{array}{l}\text { deGrip, Van } \\
\text { Loo et al }\end{array}$ & \multicolumn{3}{|l|}{ Capability } & $\begin{array}{l}\text { Capabilit } \\
\text { y }\end{array}$ & $\begin{array}{l}\text { Willingne } \\
\text { ss }\end{array}$ & \multicolumn{2}{|l|}{ Capability } \\
\hline & & & $\begin{array}{l}\text { Willingne } \\
\text { ss }\end{array}$ & & & & \\
\hline $\begin{array}{l}\text { Forrier and } \\
\text { Sels }\end{array}$ & $\begin{array}{l}\text { Movement } \\
\text { Capital } \\
\text { (MC } \\
\text { Activities } \\
\text { to maintain } \\
\text { or enhance }\end{array}$ & & $\begin{array}{l}\text { Willingne } \\
\text { ss to } \\
\text { maintain } \\
\text { or } \\
\text { enhance } \\
\text { MC }\end{array}$ & \multicolumn{2}{|l|}{ Transition } & $\begin{array}{l}\text { Context } \\
\text { Opportuni } \\
\text { ty to } \\
\text { maintain } \\
\text { or } \\
\text { enhance }\end{array}$ & $\begin{array}{l}\text { Labour } \\
\text { market } \\
\text { position } \\
\text { Shock Event } \\
\text { Opportunity }\end{array}$ \\
\hline
\end{tabular}




\begin{tabular}{|c|c|c|c|c|c|}
\hline & $\begin{array}{l}\text { MC } \\
\text { Willingnes } \\
\text { s to move }\end{array}$ & $\begin{array}{l}\text { Ease of } \\
\text { movemen } \\
t\end{array}$ & & $\mathrm{MC}$ & $\begin{array}{l}\text { to maintain or } \\
\text { enhance MC }\end{array}$ \\
\hline $\begin{array}{l}\text { Brown, } \\
\text { Hesketh, and } \\
\text { Williams }\end{array}$ & \multicolumn{2}{|c|}{ Absolute employability } & & $\begin{array}{l}\text { Relative } \\
\text { employabi } \\
\text { lity }\end{array}$ & \\
\hline $\begin{array}{l}\text { Knight and } \\
\text { Yorke }\end{array}$ & $\begin{array}{l}\text { Understan } \\
\text { ding } \\
\text { Skills } \\
\text { Metacognit } \\
\text { ion }\end{array}$ & Efficacy & & & \\
\hline \multirow[t]{2}{*}{$\begin{array}{l}\text { Harvey, } \\
\text { Locke, and } \\
\text { Morey }\end{array}$} & $\begin{array}{l}\text { Subject } \\
\text { area }\end{array}$ & $\begin{array}{l}\text { Willingne } \\
\text { ss to } \\
\text { develop }\end{array}$ & 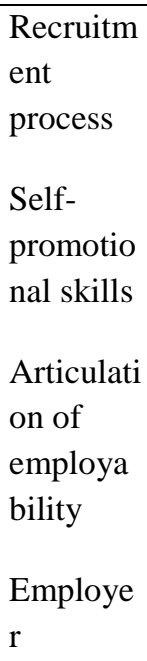 & $\begin{array}{l}\begin{array}{l}\text { External } \\
\text { factors }\end{array} \\
\text { Graduate } \\
\text { Employab } \\
\text { ility } \\
\text { developm } \\
\text { ent } \\
\text { opportunit } \\
\text { ies }\end{array}$ & $\begin{array}{l}\text { External } \\
\text { factors }\end{array}$ \\
\hline & \multicolumn{2}{|c|}{$\begin{array}{l}\text { Employability attributes } \\
\text { Engagement } \\
\text { reflection } \\
\text { pedagogy }\end{array}$} & & & $\begin{array}{l}\begin{array}{l}\text { Extra- } \\
\text { curricular } \\
\text { experiences }\end{array} \\
\text { HEI }\end{array}$ \\
\hline $\begin{array}{l}\text { Kluytmans } \\
\text { and Ott }\end{array}$ & $\begin{array}{l}\text { Applicable } \\
\text { know-how } \\
\text { and skills }\end{array}$ & $\begin{array}{l}\text { Willingne } \\
\text { ss to be } \\
\text { mobile }\end{array}$ & $\begin{array}{l}\text { Know- } \\
\text { how job } \\
\text { market }\end{array}$ & & \\
\hline Hillage and & \multicolumn{2}{|c|}{ The Assets an individual } & Deploym & The & The context \\
\hline
\end{tabular}




\begin{tabular}{|l|l|l|l|l|l|l|}
\hline Pollard & $\begin{array}{l}\text { possesses in term of knowledge, } \\
\text { skills and attitudes (baseline, } \\
\text { Intermediate, High level) }\end{array}$ & $\begin{array}{l}\text { ent of } \\
\text { those } \\
\text { assets } \\
\text { Presentat } \\
\text { ion of } \\
\text { those } \\
\text { assets }\end{array}$ & & $\begin{array}{l}\text { context } \\
\text { within } \\
\text { which } \\
\text { they seek } \\
\text { work } \\
\text { (labour } \\
\text { market } \\
\text { circumsta } \\
\text { nces) }\end{array}$ & $\begin{array}{l}\text { within which } \\
\text { they seek } \\
\text { work } \\
\text { (personal } \\
\text { circumstances } \\
\text { ) }\end{array}$ \\
\hline $\begin{array}{l}\text { Arthur, } \\
\text { Claman, and } \\
\text { DeFillippi }\end{array}$ & $\begin{array}{l}\text { Knowing } \\
\text { how }\end{array}$ & $\begin{array}{l}\text { Know } \\
\text { ing } \\
\text { whom }\end{array}$ & & Knowing & & \\
why & & & & \\
\end{tabular}




\section{Conclusions}

This manuscript offers the first systematic search of English language employability literature, adding an index to the employability field that can be used to signpost relevant literature and areas of consensus.

A total of 16 conceptualisations were identified herein, consisting of 88 components with three overarching dimensions that describe the nature of these components. Consideration of how these dimensions have developed following successive publications and interpretations suggests that more recent publications do not add to all dimensions of employability, and that the development of dimensions is inconsistent with a continuous progression of this concept.

Rather than illustrating the superiority of a single theory in understanding employability, this review provides evidence for a need to combine theorising around capital, signalling, identity, career management and labour market demand so as to better understand employability. What is more, this review offers a justification for the inclusion of theoretical developments within the areas of perceived employability, orientation models, career management, capital, and demographic components such as age and health status, within a holistic conceptualisation of employability. Only through the consideration of this plurality of factors can we truly further the conceptualisation of employability and therefore successfully inform the design and measurement of employability development interventions.

The current review must be considered within the context of its limitations. Given the diversity of the empirical testing for these conceptualisations, influenced by varying descriptions of what employability is (e.g. adaptability, knowledge and skills), the proceeding review does not include consideration of the quality of empirical support for these conceptualisations. Furthermore, whilst efforts have been made to consider a holistic view of employability at an individual level, not all of these manuscripts express employability from the same perspective or for the same purpose. Researchers are therefore advised to utilise this review as a map of existing literature from which to extract those conceptualisations that best inform their viewpoint. 


\section{Reference list}

Arkes, J. (1999). What do educational credentials signal and why do employers value credentials? Economics of Education Review, 18(1), 133-141.

Arthur, M. B., Claman, P. H., \& DeFillippi, R. J. (1995). Intelligent enterprise, intelligent careers. Academy of Management Executive, 9(4), 13.

Bandura, A. (1997). Self-Efficacy in Changing Societies Cambridge University Press.

Becker, G. S. (1962). Investment in human capital: A theoretical analysis. The journal of political economy, 9-49.

Bourdieu, P. (2008). 15 The Forms of Capital. Readings in economic sociology, 4, 280.

Bridgstock, R. (2009). The graduate attributes we've overlooked: Enhancing graduate employability through career management skills. Higher Education Research \& Development, 28(1), 31-44.

Briscoe, J. P., \& Hall, D. T. (2006). The interplay of boundaryless and protean careers: Combinations and implications. Journal of Vocational behavior, 69(1), 4-18.

Brown, P., \& Hesketh, A. (2004). The Mismanagement of Talent: Employability and Jobs in the Knowledge Economy Oxford: Open university Press.

Brown, P., Hesketh, A., \& Wiliams, S. (2003). Employability in a knowledge-driven economy. Journal of education and work, 16(2), 107-126.

Clarke, M. (2008). Understanding and managing employability in changing career contexts. Journal of European Industrial Training, 32(4), 258-284.

Connelly, B. L., Certo, S. T., Ireland, R. D., \& Reutzel, C. R. (2011). Signaling theory: A review and assessment. Journal of Management, 37(1), 39-67.

Cremin, C. (2009). Never employable enough: The (im) possibility of satisfying the boss's desire. Organization. , 1-19.

Dacre-Pool, L. D., \& Sewell, P. (2007). The key to employability: developing a practical model of graduate employability. Education+ Training, 49(4), 277289.

de Grip, A. J., van Loo, J., \& Sanders, J. (2004). The Industry Employability Index: Taking account of supply and demand characteristics. International Labour Review, 143(3), 211 -233.

De Vos, A., \& Soens, N. (2008). Protean attitude and career success: The mediating role of self-management. Journal of Vocational behavior, 73(3), 449-456. 
Eby, L. T., Butts, M., \& Lockwood, A. (2003). Predictors of success in the era of the boundaryless career. Journal of Organizational Behavior, 24(6), 689-708.

Forrier, A., \& Sels, L. (2003). The concept employability: A complex mosaic. International journal of human resources development and management, 3(2), 102-124.

Fugate, M., Kinicki, A. J., \& Ashforth, B. E. (2004). Employability: A psycho-social construct, its dimensions, and applications. Journal of Vocational behavior, 65(1), 14-38.

Grazier, B. (1998). Employability: Concepts and Policies (pp. 1-20). European Employment Observatory: European Commission.

Hall, D. T. (2004). The protean career: A quarter-century journey. Journal of Vocational behavior, 65(1), 1-13.

Harvey, L. (2001). Defining and measuring employability. Quality in higher education, 7(2), 97-109.

Harvey, L., Locke, W., \& Morey, A. (2002). Enhancing employability, recognising diversity: making links between higher education and the world of work. .

Hillage, J., \& Pollard, E. (1998). Employability: developing a framework for policy analysis. Labour Market Trends, 107, 83-84.

Hogan, R., Chamorro-Premuzic, T., \& Kaiser, R. B. (2013). Employability and career success: Bridging the gap between theory and reality. Industrial and Organizational Psychology, 6(1), 3-16.

Judge, T. A., \& Bono, J. E. (2001). Relationship of core self-evaluations traits-selfesteem, generalized self-efficacy, locus of control, and emotional stability-with job satisfaction and job performance: A meta-analysis. Journal of applied Psychology, 86(1), 80.

Kluytmans, F., \& Ott, M. (1999). Management of employability in the Netherlands. European Journal of Work and Organizational Psychology, 8(2), 261-272.

Knight, P. T., \& Yorke, M. (2003). Employability and good learning in higher education. Teaching in Higher Education, 8(1), 3-16.

Kwon, S.-W., \& Arenius, P. (2010). Nations of entrepreneurs: A social capital perspective. Journal of Business Venturing, 25(3), 315-330.

Luthans, F. (2002). Positive organizational behavior. Developing and managing psychological strengths. Academy of Management Executive, 16(1), 57-72.

McArdle, S., Waters, L., Briscoe, J. P., \& Hall, D. T. T. (2007). Employability during unemployment: Adaptability, career identity and human and social capital. Journal of Vocational behavior, 71(2), 247-264. 
McQuaid, R. W., \& Lindsay, C. (2005). The concept of employability. Urban studies, 42(2), 197-219.

Nauta, A., van Vianen, A., van der Heijden, B., van Dam, K., \& Willemsen, M. (2009). Understanding the factors that promote employability orientation: The impact of employability culture, career satisfaction, and role breadth self-efficacy. Journal of Occupational \& Organizational Psychology, 82(2), 233-251.

QUIŃONES, M. A., Ford, J. K., \& Teachout, M. S. (1995). The relationship between work experience and job performance: A conceptual and meta-analytic review. Personnel Psychology, 48(4), 887-910.

Rynne, S. (2014). 'Fast track'and 'traditional path'coaches: affordances, agency and social capital. Sport, Education and Society, 19(3), 299-313.

Shaffer, M. A., Kraimer, M. L., Chen, Y.-P., \& Bolino, M. C. (2012). Choices, challenges, and career consequences of global work experiences: A review and future agenda. Journal of Management, 38(4), 1282-1327.

Smetherham, C. (2006). Firsts among equals? Evidence on the contemporary relationship between educational credentials and the occupational structure. Journal of Education and Work, 19(1), 29-45.

Spence, M. (1973). Job market signaling. The quarterly journal of Economics, 87(3), 355-374.

Thijssen, J. G., Van der Heijden, B. I., \& Rocco, T. S. (2008). Toward the employability-link model: current employment transition to future employment perspectives. Human Resource Development Review, 7(2), 165-183.

Tomlinson, M. (2007). Graduate employability and student attitudes and orientations to the labour market. Journal of Education and Work, 20(4), 285-304.

Van Dam, K. (2004). Antecedents and consequences of employability orientation. European Journal of Work and Organizational Psychology, 13(1), 29-51.

Van Der Heijde, C. M., \& Van Der Heijden, B. I. (2006). A competence-based and multidimensional operationalization and measurement of employability. Human resource management, 45(3), 449-476.

Werbel, J. D. (2000). Relationships among career exploration, job search intensity, and job search effectiveness in graduating college students. Journal of Vocational Behavior, 57(3), 379-394. 